\title{
Gastric bleeding reduced upon switch from haemodialysis to CAPD
}

\author{
Ch. Ram Reddy • G. Swarnalatha $\cdot$ R. Ram • \\ K. V. Dakshinamurty
}

Received: 20 October 2011 / Accepted: 7 December 2011/Published online: 19 January 2012

(C) Japanese Society of Nephrology 2012

We present the case of a 65 -year-old woman who has been on maintenance haemodialysis for end stage renal disease (ESRD) due to type 2 diabetes mellitus and hypertension for the past 6 years. She was on regular recombinant erythropoietin therapy. She presented with history of melaena of 1 week duration and vomiting of 2 days duration. She also complained of haematemesis of 1 day duration. The haemoglobin had reduced from 12.0 to $4.0 \mathrm{~g} /$ $\mathrm{dL}$. The weekly changes in mean arterial pressure, haematocrit, dose of erythropoietin and serum creatinine are depicted in supplementary Fig. 1. The gastrointestinal endoscopy (Fig. 1, supplementary Figs. 2, 3) revealed gastric antral vascular ectasia (GAVE). On gastric biopsy the histologic changes included superficial hyperplastic antral mucosa, capillary ectasia with thrombosis, and fibromuscular hypertrophy of the lamina propria. Argon plasma coagulation was done six times over 1 month, but the melaena did not subside. She was given heparin-free haemodialysis sessions to reduce melaena. The recombinant human erythropoietin and intravenous iron sucrose requirements increased over a 2-month period. Despite that, she became transfusion dependent. As a result of repeated blood transfusions, she had seroconverted to hepatitis $\mathrm{C}$ virus as confirmed by third-generation ELISA. Her HCV RNA level was $40 \times 10^{6}$ copies $/ \mathrm{mL}$. The patient was then switched to continuous ambulatory peritoneal

Electronic supplementary material The online version of this article (doi:10.1007/s13730-011-0003-0) contains supplementary material, which is available to authorized users.

Ch. Ram Reddy · G. Swarnalatha · R. Ram $(\bowtie)$.

K. V. Dakshinamurty

Nizam's Institute of Medical Sciences, Punjagutta, Hyderabad, India

e-mail: ram_5_1999@yahoo.com dialysis (CAPD) and haemodialysis was discontinued. After adequate training and initiation of regular CAPD exchanges, the haemoglobin stabilized at $8.2 \mathrm{~g} / \mathrm{dL}$, without requiring further blood transfusions.

A few retrospective reports suggest that GAVE might be a cause of $19-32 \%$ gastrointestinal tract bleeding episodes in patients with chronic renal failure [1]. These lesions are located mainly in the stomach and the duodenum but the jejunum and the colon could also be affected [1].

In a recent series of 45 patients with typical GAVE, six patients had chronic renal failure [2]. GAVE in patients with ESRD is a serious condition that can cause either acute or chronic upper gastrointestinal bleeding. This condition should be considered in patients with upper gastrointestinal bleeding and those with iron deficiency anaemia, which frequently presents as recombinant human erythropoietin resistance in patients with ESRD [3].

This form of angiodysplastic lesion confined to the gastric antrum was first described in 1953 by Rider et al. [4] and named antral vascular ectasia. The term watermelon stomach was coined in 1984 by Jabbari [5], owing to its endoscopic features like longitudinal gastric antral folds containing visible vessels radiating from the pylorus and resembling the skin of a watermelon. The absence of signs of gastric inflammation on biopsy rules out haemorrhagic antritis, a frequent misdiagnosis. As biopsy carries only a minimal risk of haemorrhage, it should always be performed.

Pharmacologic therapies have been described with the use of corticosteroids, estrogen-progesterone combinations, tranexamic acid, thalidomide, $\alpha$-interferon, calcitonin, and cyproheptadine. Endoluminal therapies include endoscopic band ligation, sclerotherapy, heater probe, and argon plasma coagulation (APC), which are emerging as the preferred endoscopic therapy. In addition surgery can also be tried. 


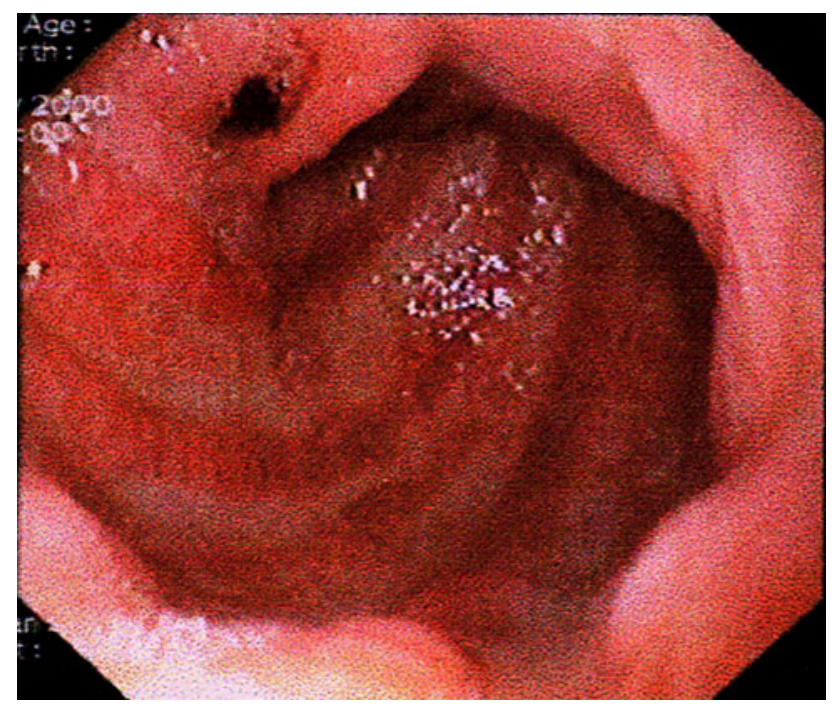

Fig. 1 Water melon stomach on gastric endoscopy

There were two reports [3, 6] of GAVE in CAPD patients. In one of them APC was successful in reducing the gastrointestinal bleed and corrected anaemia. In the second report upper gastrointestinal bleeding recurred because the patient did not consent to undergo endoscopic treatment on a regular basis. There was only one report of successful reduction of gastrointestinal bleeding due to GAVE by shifting the patient from haemodialysis to CAPD [7]. In three other patients undergoing haemodialysis there was no requirement to shift to CAPD [2, 6, 8]. In our patient the shift from haemodialysis to CAPD was necessitated owing to the continued melaena even after argon photocoagulation.

Conflict of interest None of the authors have conflicts of interests.

\section{References}

1. Hermans C, Goffin E, Horsmans Y, Laterre E, Van Ypersele de Strihou C. Watermelon stomach. An unusual cause of recurrent upper GI tract bleeding in the uraemic patient: efficient treatment with oestrogen-progesterone therapy. Nephrol Dial Transplant. 1996;11:871-4.

2. Gostout CJ, Viggiano TR, Ahlquist DA, Wang KK, Larson MV, Balm R. The clinical and endoscopic spectrum of the watermelon stomach. J Clin Gastroenterol. 1992;15:256-63.

3. Stefanidis I, Liakopoulos V, Kapsoritakis AN, et al. Gastric antral vascular ectasia (watermelon stomach) in patients with ESRD. Am J Kidney Dis. 2006;47:e77-82.

4. Rider JA, Klotz AP, Kirsner JB. Gastritis with veno-capillary ectasia as a source of massive gastric hemorrhage. Gastroenterology. 1953;24:118-23.

5. Jabbari M, Cherry R, Lough JO, Daly DS, Kinnear DG, Goresky CA. Gastric antral vascular ectasia: the watermelon stomach. Gastroenterology. 1984;87:1165-70.

6. Tomori K, Nakamoto H, Kotaki S, et al. Gastric angiodysplasia in patients undergoing maintenance dialysis. Adv Perit Dial. 2003;19: $136-42$.

7. Yorioka N, Hamaguchi N, Taniguchi Y, Asakimori Y, Nishiki T, Oda $\mathrm{H}$, et al. Gastric antral vascular ectasia in a patient on hemodialysis improved with CAPD. Perit Dial Int. 1996;16:177-8.

8. Pljesa S, Golubovic G, Tomasevic R, Markovic R, Perunicic G. "Watermelon stomach" in patients on chronic hemodialysis. Ren Fail. 2005;27:643-6. 